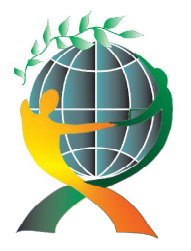

\author{
(online) $=$ ISSN $2285-3642$ \\ ISSN-L = $2285-3642$ \\ Journal of Economic Development, Environment and People \\ Volume 4, Issue 4, 2015 \\ URL: http://jedep.spiruharet.ro \\ e-mail: office_jedep@spiruharet.ro
}

\title{
Improving VAT Compliance in Romania by Implementing a New Tool - Tax Lottery Receipts ${ }^{1}$
}

\author{
Dragoș Mihai UNGUREANU, Elena-Doina DASCĂLU \\ Spiru Haret University, Faculty of EconomicSciences, 46 G Fabricii Str., District 6 Bucharest, \\ Romania, Tel: 021 3169785, Email: dragos.ungureanu@yahoo.com, doina.dascalu@rcc.ro
}

\begin{abstract}
This paper aims to present and explain the newly implemented measure of organizing a Tax Lottery Receipts in Romania, in orderto combat tax evasion by raising awareness among consumers and make them responsible when purchasing any goods. The lottery proposes an approach to strengthen the fiscal voluntary conformation by stimulating financially those who promote respecting the law asking for the fiscal receipt, and helpthe fiscal authorities this way in the fight against tax evasion, contrasting at the same time with punishing those who do not respect it - not issuing fiscal receipts.
\end{abstract}

Keywords: fiscal receipt, tax evasion, fiscal voluntary conformation.

JEL classification: E60, E62, H20, H26

\section{The Concept of a Tax Receipt Lottery}

To fight and cut down tax evasion is a concern for all economies around the world. The lower the rate of evasion, the more and attractive the economy gets for foreign investors and the management of taxes and duties becomes more efficient. The classic mechanisms used to reach this aim are mostly coercive measures based on punishment, usually financial.

The concept of a tax receipts lottery is based on the idea that a consumer purchase is much easier to record in the official economy, where it can be taxed by the authorities, if sellers issue a fiscal receipt to the customer. In some countries, if an advanced cash register system is in place which directly communicate transactions to the tax authorities, all transactions for which a receipt is issued will be taxed. In any case, once a receipt is issued it becomes more difficult for sellers to evade VAT, independent of the cash register system of a country.

1 The article was previous presented at International Conference on Economic Sciences and Business Administration 2015 


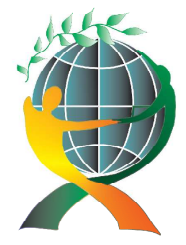

\author{
(online) $=$ ISSN $2285-3642$ \\ ISSN-L $=2285-3642$ \\ Journal of Economic Development, Environment and People \\ Volume 4, Issue 4, 2015 \\ URL: http://jedep.spiruharet.ro \\ e-mail: office jedep@spiruharet.ro
}

The tax lottery involves an approach based on motivating and rewarding those who are part in the efforts to fight tax evasion; people who abide by the law (they ask for the receipt) are awarded, in opposition to those who evade the law (do not give the receipt) and are punished. The tax lottery might help to prevent and fight tax evasion, given that the buyer, when asking for a supportive document (which they will use to join the game), cuts down significantly the chance of the seller to avoid declaring the transaction. Thus, the tax lottery becomes an additional means to force economic agents to record in their accounting all the transactions carried out.

The usefulness of a receipt is significantly higher for the tax authority rather than the buyer of a product as the latter hardly ever enjoys the benefits arising from such document (e.g.: evidence of the ownership over the bought service or product). The idea of introducing such a lottery is to make the receipt (even if only psychologically) valuable to the consumer. If the receipt serves as a lottery ticket, consumers might have a reason to request it.

Tax receipts lotteries are designed to increase the issuance of receipts in business-toconsumer-transactions. This way, transactions are more likely to be part of the official (not the shadow) economy and VAT can be collected. The idea of lottery schemes is to provide consumers with an incentive to ask for a receipt. The incentive is that the receipt is not just a piece of paper documenting the transaction made, but serves as a (potential) lottery ticket, giving consumers eligibility to participate in a tax lottery. The lottery in turn gives the chance to win a prize if for a randomly drawn receipt. Hence, while obtaining the receipt is (for any legal transaction) of no extra cost to the consumer, it becomes valuable, as it serves as a lottery ticket. For the tax authority the cost of paying prizes (and administering the lottery) should be, in turn, outweighed by the extra revenue of an increased tax base, and by a citizen-policing effect of detecting VAT-dodging businesses ${ }^{2}$.

In terms of tax management, the tax lottery comes to partially replace the efforts of the tax inspectors regarding the enforcement of compliance with the law, namely the issuance of receipts for transactions. In terms of the cost-benefit ratio, this facility proves a very good one as all buyers become potential tax inspectors and the costs are limited to the rewards given and the management of the receipts submitted for lottery ${ }^{3}$.

\footnotetext{
${ }^{2}$ Fooken J., Hemmelgarn T., Herrmann B. - Improving VAT compliance - random awards for tax compliance, Taxation papers, Working paper no. 51, 2014

${ }^{3}$ Ungureanu M.D., Dascălu D., Tax Lottery Receipts in Romania, a Different Approach to Fight Against Tax Evasion, International Conference on Economic Sciences and Business Administration, 20-21 noiembrie 2015
} 


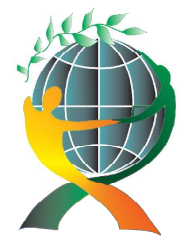

\author{
(online) $=$ ISSN $2285-3642$ \\ ISSN-L $=2285-3642$ \\ Journal of Economic Development, Environment and People \\ Volume 4, Issue 4, 2015 \\ URL: http://jedep.spiruharet.ro \\ e-mail: office jedep@spiruharet.ro
}

\title{
2. Tax Lottery Receipts Abroad
}

The use of receipt-based tax lotteries to increase (VAT) tax compliance has been of growing interest amongst EU Member States. Some countries have introduced such lottery schemes, namely Malta, Slovakia and Portugal. Others have been intrigued about the possibility of introducing a lottery. The use of tax lotteries also has a history outside of Europe, notably in Taiwan since the 1950s.

\section{Malta}

Malta has been the first European country to introduce a tax receipts lottery, as early as 1997, and consequently has a long history and experience with running the lottery. To give the audience a better idea, first the lottery was put into the scope of Malta, as some particularities of Malta as an island-state have to be taken into account when contemplating to extrapolate the Maltese lottery scheme to another (and necessarily larger) European country. That is, it was outlined that Malta is the EU's smallest Member State, with a population of about 400 000living in a geographically small area. Furthermore, the role of VAT in the government budget was outlined, with EUR 587 million. VAT revenues being responsible for raising $22 \%$ of government income. It was also outlined that the issuing of receipts for business-to-consumer purchases is important for the tax authority to know the tax base. For this reason it is also a legal obligation (though it cannot be legally sanctioned) for customers to retain receipts from purchases for 24 hours after the purchase has been made. This obligation was introduced into the legislation to facilitate field audits. A similar motivation as for this legal obligation to get a fiscal receipt in purchases is the reason for the existence of the Maltese tax receipts lottery. Hence, the lottery is seen to provide consumers with an incentive to ask for the receipt and keep it, which in turn makes it easier for tax authorities to control VAT compliance.

Lottery winners are paid 100 times the fiscal receipt, within a range of EUR 233 - EUR 11 647 respectively. So gains for receipts under EURO 233 and above EURO 116.47 are brought to the minimum ceiling or maximum fixed to fit in amounts required by law. The monthly budget allocated tax lottery amounts to EURO 50,000, thereby allowing a greater number of winners. There is no limit on the number of receipts that a person can participate in the lottery with.

Practically, the lottery is done by mixing all participating fiscal receipts in a large drum, organised by the Department of Lotto. The draw is public, conducted in a public place and supervised by an ad-hoc board. There are representatives from the Notary to Government, VAT department, the Lotto department, the National Audit Office, the public present at the drawing, so to become more transparent. 


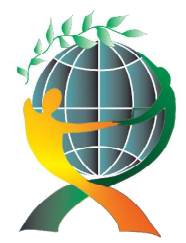

\author{
(online) $=$ ISSN $2285-3642$ \\ ISSN-L = $2285-3642$ \\ Journal of Economic Development, Environment and People \\ Volume 4, Issue 4, 2015 \\ URL: http://jedep.spiruharet.ro \\ e-mail: office jedep@spiruharet.ro
}

While no major data analysis takes place in the course of the lottery, some figures have been recorded. It has been observed that the lottery is becoming more popular with a tendency of a rising number of receipts submitted for the lottery, with 32.5 million in 2007up to 35.7 million in 2013. While this is an indicator of the sustained popularity of the lottery, no scientific or quantitative evaluation of the success of the lottery has been conducted. Hence, it is not known whether the lottery has increased VAT compliance in the short or long term.

The Maltese lottery system has flaws, as shown in the case where several withdrawals in 2002 and 2003 were schemed, involving 11 people, 3 of the organizers.

We can identify some of the characteristics of Maltese tax lottery ${ }^{4}$ : receipts are centralized in a physical format for each withdrawal, it takes time to complete the personal data on each ticket and prize value is capped at Euros 11.647. We conclude that participation in the lottery is not free, because sending bills involves costs; the management of unsuccessful receipts also presumes costs for their destruction and the system is not sufficiently transparent as there is no certainty that the receipts are the box.

Slovakia

The tax lottery scheme in Slovakia has been introduced in the second half of $2013^{5}$, receiving widespread media attention and causing a large increase in interest regarding the use of such lottery schemes across Europe.

While the effective tax rate (the share of VAT revenues in the tax base) had been rising in Slovakia prior to joining the European Union (EU), since Slovakia's membership in the EU in 2005 it had been significantly falling, reaching levels that were much worse than EU average and also clearly lower than during the pre-EU era. Also the VAT gap (the difference between collected VAT and the VAT that should be collected if all transactions were legal) had been one of the highest in Europe and almost twice the EU average in 2011. Furthermore, the VAT gap had been increasing from its low point of $18.2 \%$ in 2003 to a high point of $40.1 \%$ in 2012 . Hence, tax evasion, and VAT evasion in particular, was a pressing issue for government revenues. For this reason, concerted efforts to reduce tax evasion were launched in 2012, and the tax receipts lottery was part of these efforts.

In order to understand the sources of the tax gap, authorities took several steps. One included the identification of problematic candidates, that is, sectors in which VAT evasion is more prevalent. This identified some usual suspects in agriculture, construction, wholesale and retail trade, hotels and restaurants, as well as (surprisingly) also in the

\footnotetext{
${ }^{4}$ Ungureanu M.D., Dascălu D., Tax Lottery Receipts in Romania, a Different Approach to Fight Against Tax Evasion, International Conference on Economic Sciences and Business Administration, 20-21 noiembrie 2015 ${ }^{5}$ Cunningham B. - Slovakia Fights Corruption with Sales Tax Lottery, Spiegel Online, 2013
} 


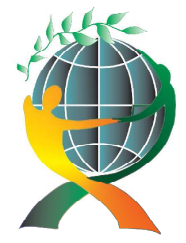

\author{
(online) $=$ ISSN $2285-3642$ \\ ISSN-L = $2285-3642$ \\ Journal of Economic Development, Environment and People \\ Volume 4, Issue 4, 2015 \\ URL: http://jedep.spiruharet.ro \\ e-mail: office jedep@spiruharet.ro
}

professional services industry. As a result an action plan was introduced to combat tax evasion. Most of the plan included typical control measures, which made the monitoring and detection of tax evaders easier from the side of the authorities. Furthermore, it was decided to introduce the tax receipts lottery, which has a much stronger behavioural component and involves participation and support by third parties, namely normal citizens involved in consumer transactions. The lottery in this context had namely the aims of being a tool for communicating the importance of VAT compliance to citizens, to increase surveillance by the citizens, and ultimately to improve the ability to collect taxes more effectively. As for the case of Malta, the logic behind the introduction of the lottery was to motivate consumers to ask for a receipt and to get them involved in - comparatively mild - citizen policing in daily transactions.

The rules for the lottery were that all receipts with value of EUR 1or higher were eligible to participate. Furthermore, receipts were only valid to be registered in the lottery for two months after the purchase. In order for a consumer to participate in the lottery, receipts had to be registered using any of four alternative channels: online via the internet, via a SMS text message, through the National Lottery Company which served as the operator of the lottery, or through automatic registration by the retailer issuing the receipt. In order to be registered in the lottery draw, the registration had to include the unique identification number of the cash register issuing the receipt, the date and time of the transaction, and the amount of the transaction.

The lottery was operated by the National Lottery Company and implemented similar to a regular lottery. Prizes were awarded with equal chance for every receipt, independent of the value of the purchase. Each submitted receipt had a chance of winning via three difference channels, named the first, second and third chance. The first chance included a draw every two weeks in which ten prizes valued from EUR 100 to EUR 10000 were awarded. This represents a significant amount and corresponds to 0.12 to 12 times the average monthly wage. The second chance in turn is drawn once per month and is based on regional characteristics. More specifically, in this draw there was one winner each from the 8 administrative regions of Slovakia. The winner in this monthly draw was one particular cash register, and a second lottery amongst all receipts submitted using this register was drawn. In this lottery both financial and non-financial (a car) prizes were drawn, and under the current framework each winner of this lottery receives a EUR 5000 cash prize. Finally, a third chance was used over all submitted receipts, in which the winner became eligible in a TV show ('The prize is right').

Since the introduction of the lottery scheme, it has proven to be popular, with 7 million receipts registered in the first run of the lottery, and still a relatively stable number of around 3 million submitted every two weeks. In total about $10 \%$ of the population registered to participate in the lottery at least once.The number of individuals 


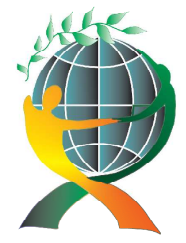

\author{
(online) $=$ ISSN $2285-3642$ \\ ISSN-L = $2285-3642$ \\ Journal of Economic Development, Environment and People \\ Volume 4, Issue 4, 2015 \\ URL: http://jedep.spiruharet.ro \\ e-mail: office jedep@spiruharet.ro
}

participating in the lottery has declined before becoming more stable around 80000 (total population is 5.4 million inhabitants). Most players come from the Bratislava region.Nonsurprisingly, the by far largest share of receipts is sourced from the retail sector, again here with a concentration on big retail chains. This also hinted to a short coming of the lottery, as these chains tend to issue receipts for purchases or at least formally register the transaction anyway; hence, the extra gain through policing due to the lottery is minimal. On the contrary, the more problematic service industry (in terms of tax evasion) is only responsible for $2 \%$ of submitted receipts. Hence, from the big shot of the lottery only a small hit is reaching the main target of these problematic candidates.

There was also some first analysis on the impact of the lottery in fiscal terms. The analysis of success factors focussed on small companies, as those are suspected to be those more likely to engage in tax evasion. For similar reasons there was also a focus on service industries. However, first analysis did not show a significant increase of revenue from particular firms from whom also more receipts had been issued. There was, however, a higher rate of sales increases from the pre- to the post-lottery period in small retail compared to the sales increase in larger retailers. However, the attribution of this increase is not identifiable to the lottery alone, mainly due to the multiple channels with which improved tax compliance was promoted. It was also discussed that the policing of sellers not issuing receipts has been increased, however, the impact of this measure (and the cost-effectiveness compared to other measures) has not yet been assessed. The fiscal impact of the lottery is estimated to be modest, leading to extra revenue of about EUR 8 million annually when extrapolating from the experience in the last quarter of 2013 and when basing the effect from a focus on restaurants and retailers (who are, however, arguably the most critical sectors; i.e.most of the effect should accrue in these sectors). This compares to initial costs of EUR 1.6 million, which included marketing. Total cost in 2014 is in turn estimated to be another EUR 1.6 million. While this indicates that the lottery would break-even, it is generally judged to be of modest impact compared to other available measures in fighting tax evasion.

The Slovak tax lottery does not enjoy great popularity as registration is cumbersome ${ }^{6}$. Sending or dictating to the vendor whole ranks of codes involves patience and can be easily mistaken, which invalidates the gain.

\title{
Portugal
}

A tax invoice and receipts lottery on all VAT relevant transactions was implemented in Portugal too, called 'Lucky Invoice Lottery' ${ }^{7}$. This lottery is again similar to the tax receipts

\footnotetext{
${ }^{6}$ Ungureanu M.D., Dascălu D., Tax Lottery Receipts in Romania, a Different Approach to Fight Against Tax Evasion, International Conference on Economic Sciences and Business Administration, 20-21 noiembrie 2015 ${ }^{7}$ Wise P. - Portugal tries its luck with tax lottery, Financial Times Online, 2014
} 


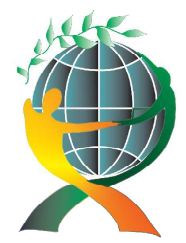

\author{
(online) $=$ ISSN $2285-3642$ \\ ISSN-L = $2285-3642$ \\ Journal of Economic Development, Environment and People \\ Volume 4, Issue 4, 2015 \\ URL: http://jedep.spiruharet.ro \\ e-mail: office jedep@spiruharet.ro
}

lotteries described by other countries before. More particularly, there is one random draw per week (on Thursday, starting from April 2014) selecting winning receipts that have been submitted to the lottery. Furthermore, there are two semi-annual draws, in June and December, for an 'extraordinary lottery'. All draws are publicly broadcasted on TV to gain widespread attention. The weekly draw of the regular lottery works on the basis of socalled coupons. Individuals can get coupons to the lottery by registering invoices or having them registered by sellers. The number of coupons an individual receives is dependent on the value of the receipt that is registered for the lottery. The higher the amount of the purchase, the higher the number of coupons, as one coupon is assigned to each multiple of EUR 10 in the receipt. If the lowest fraction is below EUR 10, a coupon is assigned (an invoice of EUR 10.20would for example get two coupons assigned). There is no limit on the number of coupons per individual in each draw. Every coupon has an equal chance of winning a prize in the lottery, whereas the prize is to win an Audi A4 each draw. The biannual draw again provides a second chance to win with the same coupons, whereas in this draw the lottery runs over three Audi A6per draw.

Winners are informed about their winnings using the online platform. Winners can then decide if they would like to claim the prize themselves or if they would like to donate the prize. They can also decide to receive the prize with or without public attention. Finally, also the issuer of the receipt is informed about the fact that one of its receipts has won in the lottery.

The experience with the lottery scheme so far is relatively limited. The first draw was on April 17, 2014 over 207million coupons and with 7.9million buyers and 171000 issuer companies involved. Given the size of Portugal, this can be seen as significant participation. The draw was broadcasted live on television, attracting 600,000 viewers.

While no evaluation of the lottery scheme exists, it can be considered a success and further steps are currently in planning, including an App to the platform to be usable for mobile phones.

The Portuguese tax lottery system is overly bureaucratic ${ }^{8}$ lottery in order to provide equal opportunities to everyone. Also offering prizes in goods is a disadvantage and that's why there are stipulated mechanisms to donate the prize.

\footnotetext{
${ }^{8}$ Ungureanu M.D., Dascălu D., Tax Lottery Receipts in Romania, a Different Approach to Fight Against Tax Evasion, International Conference on Economic Sciences and Business Administration, 20-21 noiembrie 2015
} 


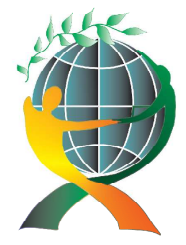

\author{
(online) $=$ ISSN $2285-3642$ \\ ISSN-L $=2285-3642$ \\ Journal of Economic Development, Environment and People \\ Volume 4, Issue 4, 2015 \\ URL: http://jedep.spiruharet.ro \\ e-mail: office jedep@spiruharet.ro
}

\title{
3. Tax Lottery Receipts in Romania
}

In Romania, tax lottery was implemented in January $2015^{9}$, in order to fight tax evasion. A mechanism was created to stimulate citizens to ask for a receipt for every purchase. Thus, the aim was to increase taxation on the traders' income.

The drawings are held monthly on the first Sunday after the 15th of each month, taking into account tax receipts issued in the previous month. Receipts participating in the lottery must meet a number of conditions such as: have been issued by a fiscal electronic cash register, the mandatory information must be readable, have a value between 1.00 and 999.99 lei and to be issued for the period indicated for each edition. From all participating receipts, only the receipts with the winning amount can enter the competition, being issued on the day of the drawing.

The mechanism of random selection of winners is made by extracting the date and winning value. For the amount, the drawn numbers are in the range 1-999, representing the total amount of the tax receipt, without subdivisions. Also, a calendar date is drawn for the month or period when the receipts were issued. The withdrawal of the winning day and amount is made by the National Lottery, in a transparent manner.

In the lottery, prizes may be claimed at any territorial unit of the National Agency for Fiscal Administration (ANAF), by submitting the original fiscal receipt winner and a copy of the identity document of the holder, accompanied by a statement. Claiming prizes is made within 30 days of the drawing, and if the number of receipts exceeds 100 , an additional withdrawal is organized and 100 winning tickets are drawn.

The study of tax lotteries organized in other states led to two different ways of organization: tax receipts are gathered in one place from which a random withdrawal is performed; respectively tax receipts are recorded in a database from which lucky ones are drawn. The disadvantage of the first way is that the holder of the tax receipt must bear the costs of sending the receipt or a copy of it (there was considered to keep the original with the buyer to be able to continue to enjoy the guarantee of goods and to prove the licit ownership of assets) and the tax authority, after the withdrawal, was left with piles of receipts. The disadvantage of the second method was that the receipt holder should have had access to an infrastructure to send the information on the receipt (internet, mobile, etc.). Even if mobile telephony is widespread in Romania, the transmission of more than 50 characters for each voucher (tax code, cash register code, tax receipt number, buyer data etc.) required time and there is the possibility of errors that could invalidate registration. In addition, the tax authority, even seeing that the same receipt had been

\footnotetext{
${ }^{9}$ OG 10/2015 privind organizarea Loteriei bonurilor fiscale
} 


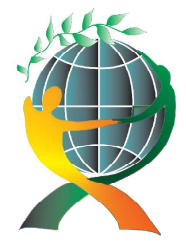

\author{
(online) $=$ ISSN $2285-3642$ \\ ISSN-L = $2285-3642$ \\ Journal of Economic Development, Environment and People \\ Volume 4, Issue 4, 2015 \\ URL: http://jedep.spiruharet.ro \\ e-mail: office jedep@spiruharet.ro
}

recorded several times, could not invalidate the additional records, not knowing who really had the tax receipts.

The solution identified to avoid the disadvantages mentioned above and to ensure maximum transparency in the organization of the tax lottery has been to extract specific elements identifiable on any tax receipt, following for the tax authority to manage and keep only fewer tax receipts. After several tests, the elements subject to random extraction have been set as the date and amount of the tax receipt (both readily identifiable on any tax receipt). In this way, the number of receipts that are submitted to the fiscal unit is reduced from about 300 million per month to a maximum of tens of thousands.

\title{
4. Conclusions
}

While the general idea of a tax lottery is relatively straightforward, the specifics of how best to design and introduce the lottery are often less clear. Also the positive fiscal effect (the cost of the lottery being outweighed by the reduction of VAT evasion) is an empirical question. Furthermore, the political economy (i.e., considerations of how to get such a scheme into the political process) of a tax lottery require consideration in advance. Additionally, the tax lottery can also serve other purposes, such as serving as a communication vehicle to the citizens to stress the importance of tax payments. They may also trigger a public discussion about the two-way character of taxes (them being more than just a tribute, but something from which citizens expect something in return).

In order to maximize the effectiveness of this tool in fighting tax evasion, the mechanism of the operation of tax lottery has been designed to respond to principles of equity, efficiency and simplicity.

The main advantages are related to reduced costs for both participants and organizers and unhindered participation of all socio-professional categories is ensured. The withdrawal of the date and amount of receipts, as implemented in tax lottery in Romania, carries other advantages, among which the most important are shown as follows.

All tax receipts issued in period of reference participate in the tax lottery. Thus, there is no discrimination between receipts from any point of view. They have equal chances, regardless of the nature of the goods or services purchased, on the quality of VAT payer of the vendor, applied VAT rate, method of payment etc. 


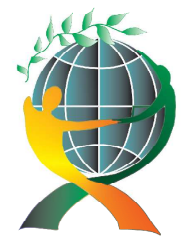

\author{
(online) $=$ ISSN $2285-3642$ \\ ISSN-L = $2285-3642$ \\ Journal of Economic Development, Environment and People \\ Volume 4, Issue 4, 2015 \\ URL: http://jedep.spiruharet.ro \\ e-mail: office jedep@spiruharet.ro
}

Waiving the principle "more receipts - more chances"10 does not make the participants in the tax lottery to ask for more receipts of low value when they make purchases, but to want to have receipts of various amounts.

The possibility of each person to claim more prizes at the same withdrawal of the tax lottery encourages people to keep receipts and to ask for them from vendors. It is true that it can encourage sellers to keep the receipts refused by buyers, but this supports both the lottery and the tax evasion. We have to say that it avoids the organization of a market of winning receipts given that each holder is interested in claiming the prize for themselves.

The withdrawal system is transparent and fair with all receipt holders. There is a fair chance for all participants having the date and amount equal to the winning ones. The 100 winners (if there are more than 100 unclaimed receipts) are also made randomly, following the same rules. Considering that the withdrawals are broadcast on TV and the results are published in the mass-media both nationally and regionally, the transparency principles are strictly promoted and observed.

The amount of the tax lottery prizes is motivating and this is shown by the recent rule that caps the number of winners to 100 for each edition. Following the studies conducted, individual prizes are usually higher than the double of the prizes offered for the third category of the most popular lottery game from Romania.

The payment of the prizes is made only in a bank account and this also helps the efforts made to encourage using money through banks and not cash.

The tax lottery from Romania is meant to become a modern tool to support the fight against tax evasion and follows the trend from other EU countries. The implementation strategy is unique, completely different from other systems. The main advantage concerns the low management costs, which sets the premises for using the money for prizes and not for administrative costs. However, the tax impact of this project and its direct benefits against tax evasion in Romania are yet to be seen and assesed.

\title{
References
}

[1] Cunningham B. - Slovakia Fights Corruption with Sales Tax Lottery, Spiegel Online, 2013, http://m.spiegel.de/international/europe/a-920439.html

[2] Da Z., Warachka M., Yun H. - Lottery Tax Windfalls, State-Level Fiscal Policy, and Consumption, 2015, http://www3.nd.edu/ zda/Lottery.pdf

[3] Fabri M., Hemels S. - "Do you want a receipt?" - Combining VAT and RST evasion with lottery tickets, http://repub.eur.nl/pub/41297/metis_191370_AMM.pdf

\footnotetext{
${ }^{10}$ Ungureanu M.D., Dascălu D., Tax Lottery Receipts in Romania, a Different Approach to Fight Against Tax
} Evasion, International Conference on Economic Sciences and Business Administration, 20-21 noiembrie 2015 
(online) $=$ ISSN $2285-3642$

ISSN-L $=2285-3642$

Journal of Economic Development, Environment and People

Volume 4, Issue 4, 2015

URL: http://jedep.spiruharet.ro

e-mail: office jedep@ spiruharet.ro

[5] Fooken J., Hemmelgarn T., Herrmann B. - Improving VAT compliance - random awards for tax complian-
ce,
Taxation
papers,
Working
paper
no.
51 ,
2014,

http://ec.europa.eu/taxation_customs/resources/documents/taxation/gen_info/economic_analysis/tax_ papers/taxation_paper_51.pdf

[6] Hansen A. - Lotteries and State Fiscal Policies, Tax Foundation, Background Paper, no. 46, 2004, http://taxfoundation.org/sites/taxfoundation.org/files/docs/0817c133300e7a38068228869414aebd.pdf

[7] Korniotis G. - Habit formation, incomplete markets, and the significance of regional risk for expected returns, Review of Financial Studies 21, 2008, p. 39-2172.

[8] Ungureanu M.D., Dascălu D., Tax Lottery Receipts in Romania, a Different Approach to Fight Against Tax Evasion, International Conference on Economic Sciences and Business Administration, 20-21 noiembrie 2015, http://issuu.com/rbmt/docs/procediaonline/0

[9] Wise P.- Portugal tries its luck with tax lottery, Financial Times Online, 2014, http://www.ft.com/intl/cms/s/0/30834f5a-919f-11e3-8fb3-00144feab7de.html\#axzz3pxn9Qurd

[9] OG 10/2015 privind organizarea Loteriei bonurilor fiscale 